\title{
LEGAL AND ECONOMIC CONSIDERATIONS IN THE DECISIONS OF JUDGE BREYER
}

\author{
Howard Latin* \\ INTRODUCTION
}

Science and law embody fundamentally different decisionmaking norms. ${ }^{1}$ When confronted by complexity and uncertainty, the scientist properly reserves judgment pending the development of testable hypotheses and sufficient data to validate theoretical predictions. From the perspective of science, many important questions must be characterized as indeterminate. Lawyers and social policymakers have no comparable opportunity to suspend judgment, because "no decision" is a decision that promotes the interests of disputants who benefit from the status quo. The primary focus of law, and the central responsibility of judges, is the resolution of conflicts in a timely and equitable manner. One implication of this responsibility is that judges and other legal decisionmakers must often rely on crude but administrable rules which preclude consideration of some scientifically or logically relevant issues. $^{2}$

In a 1983 essay, Judge Stephen G. Breyer of the United States Court of Appeals for the First Circuit made similar observations about the disciplinary perspectives of lawyers and economists. ${ }^{3}$ Judge Breyer acknowledged that legal decisionmakers in fields such as antitrust and utility regulation must have a clear understanding of pertinent economic concepts and facts. ${ }^{4} \mathrm{He}$ stressed, however, that law and regulation are "in large part administrative activities" which require rules that must be simple, fairly uniform, stable over time, capable of application by nonexperts, and, above all, useful for resolution of disputes litigated through the adversarial process. ${ }^{5}$ Judge

Copyright $@ 1988$ by Law and Contemporary Problems

- Professor of Law, Rutgers University School of Law, Newark, New Jersey.

1. See Latin, The "Significance" of Toxic Health Risks: An Essay on Legal Decisionmaking Under Uncertainty, 10 EcologY L.Q. 339, 339 (1982).

2. See id. at 355-59, 380-86; see also S. Breyer, Regulation and Its Reform 103-04 (1982); Latin, Ideal Versus Real Regulatory Efficiency: Implementation of Uniform Standards and "Fine-Tuning" Regulatory Reforms, 37 Stan. L. REv. 1267, 1275 n.30, 1329.30 (1985).

3. See Breyer, Economics for Lawyers and Judges, 33 J. LeGal Educ. 294 (1983).

4. See id. at 295. Judge Breyer noted that some rules of law adopt economic concepts, such as monopoly power, as part of a legal test, and other rules of law require proof consisting at least in part of economic evidence.

5. Id. at 296 (emphasis in original). 
Breyer noted that economists can simply find the evidence inconclusive, but lawyers must recommend outcomes despite uncertainty. ${ }^{6}$ Economists usually cannot measure all relevant variables or conduct controlled prospective studies in a continually changing world. ${ }^{7}$ Economists tend to "hold constant a broad range of variables" while they examine one in detail, 8 but lawyers typically must try to consider all material factors and must often "reject complexity" in order to achieve "justice."9 Given his emphasis on the disciplinary limitations of economics and the need for administrable legal rules, Judge Breyer unsurprisingly concluded that he had "seen few cases, if any, in the decision of which economics played an important role."10

After an examination of the approximately one hundred judicial opinions Judge Breyer authored in 1984 and 1985, I can say confidently that he has continued to emphasize legal and administrative considerations rather than economic analysis. His opinions, however, reveal a broader range of decisional criteria than those concerned primarily with the administrability of legal rules. This essay provides a relatively systematic discussion of the interplay between legal and economic factors, and explains the basis for my agreement with Judge Breyer's conclusion that legal considerations will generally prove determinative in the decisions of federal appellate judges.

Part I presents a simplified taxonomy of criteria that are important in the resolution of legal disputes. These decisional factors are organized into six general clusters: Allocation of Institutional Responsibilities, Justiciability Constraints, Unquantifiable and Incommensurable Interests, Fairness and Evenhanded Justice, Global Efficiency Effects, and Microefficiency Effects. These clusters reflect different considerations that often cut in opposite directions, and only the latter two sets of criteria fit comfortably within the purview of economic analysis. Moreover, judges seldom possess sufficient information and expertise to make reliable predictions about the effects of their decisions on the broad realms of private and institutional behavior subsumed under the "global efficiency" category. Judges consequently tend to make legal or intuitional rather than economic assessments of factors within this category. ${ }^{11}$ Thus, courts decide cases through balancing the quantifiable interests of parties in each dispute, which is the characteristic approach of conventional "law and economics" analysis, only when they conclude that "microefficiency" criteria should dominate the other five clusters of decisional factors in a specific type of case. In this taxonomy and discussion, Judge Breyer's recent opinions serve as an informal "database" to illustrate competing legal and economic considerations; however, the same

\footnotetext{
6. See id. at 296-97, 304.

7. See id. at 303-04.

8. Id. at 304 .

9. Id. at 297,304 .

10. Id. at 294.

11. See infra text accompanying notes 52-75, 129-38. For example, a judge may believe that legal predictability is important because it enables private actors to make better informed investment decisions, but the judge would never be able to quantify the economic value of this intuition.
} 
types of decisional factors would likely appear in any comparable sample of appellate cases.

Part II examines in greater depth two of Judge Breyer's decisions on torts issues with which $I$ am familiar. The results reached in those cases are arguably "inefficient," although not necessarily wrong from a legal perspective, and greater attention to economic criteria could have been used in these opinions. Nevertheless, the primary purpose of these case analyses is not to criticize Judge Breyer's treatments, but instead to demonstrate how legal and administrability concerns play a prominent role in the resolution of disputes that may be reasonably amenable to economic analysis. Federal appellate cases often present a variety of significant legal and economic considerations, and the relative weights assigned to different factors are likely to be imprecise and debatable. The central theme in this discussion is that the judicial choice among competing decisional criteria requires a legal rather than an economic judgment. Although one may disagree with Judge Breyer about the desirable outcomes in specific cases and about the comparative importance of efficiency and administrability in some legal contexts, I support his general rejection of the aggrandizing "law and economics" claim that economic considerations are, or should be, determinative in most judicial decisions.

\section{II}

\section{A Taxonomy of Common Decisional Criteria}

This section presents a taxonomy that describes systematically a number of distinctive concerns which underlie many judicial decisions, and which often counterbalance economic considerations in particular categories of cases. The catalog does not attempt to list every factor that may influence judicial decisions, and alternative arrangements of the identified criteria might prove equally satisfactory. Some factors, such as the value of predictability or strict compliance with procedural requirements, could be listed in several of the clusters. This observation simply indicates that legal principles may concurrently serve several useful purposes.

\section{A. Allocation of Institutional Responsibilities}

The authority of federal appellate courts is frequently circumscribed by their need to preserve the decisionmaking prerogatives of other institutions. This cluster of legal considerations has been more often outcomedeterminative than any other set of criteria in the decisions of Judge Breyer. In many opinions he stressed and, more important, showed deference to legislative enactments, ${ }^{12}$ agency expertise, ${ }^{13}$ Supreme Court interpretations

12. See, e.g., Diamond v. Bucci, 732 F.2d 17 (1st Cir. 1984); Doe v. Anrig, 728 F.2d 30 (1st Cir. 1984).

13. See, e.g., Distrigas of Mass. Corp. v. Federal Energy Regulatory Comm'n, 737 F.2d 1208 (1st Cir. 1984); Department of Pub. Utils. v. United States, 729 F.2d 886 (1st Cir. 1984); Distrigas of 
of federal law, ${ }^{14}$ precedents created by the federal courts of appeals, ${ }^{15}$ state court determinations of common law doctrines, ${ }^{16}$ and factual findings by trial courts $^{17}$ or administrative law judges. ${ }^{18}$ On a rough continuum between judicial activism and judicial restraint, Judge Breyer's opinions reflect a tendency toward deference and restraint rather than pathbreaking assertions of appellate court power. ${ }^{19}$ Yet, any judge would acknowledge the importance of these institutional concerns irrespective of whether they promote or impede economically efficient results in specific cases.

For example, several utility regulation cases presented Judge Breyer with the question of whether the FERC has authority to reduce future rates when it finds that the previous rate structure was unreasonable. ${ }^{20}$ If ratemaking regulation is economically justified at all, it is difficult to see any compelling economic rationale that would allow utilities to perpetuate unreasonably high revenues. ${ }^{21}$ Nevertheless, Judge Breyer held that the agency's delegated authority permits it only to reject proposed increases, not to roll back rates below previously approved levels. He reached this result through construction of the applicable statutory provision as interpreted by a Supreme Court decision he found controlling. ${ }^{22}$ Judge Breyer clearly understood the applicable economic issues-one of his opinions presents an exceptionally lucid description of economic factors relevant to the regulatory process ${ }^{23}-$

Mass. Corp. v. Boston Gas Co., 693 F.2d 1113 (1 st Cir. 1982). But see New England Tel. \& Tel. Co. v. Public Utils. Comm'n, 742 F.2d 1 (1st Cir. 1984).

14. See, e.g., Barber Lines v. Donau Maru, 764 F.2d 50 (1 st Cir. 1985); Distrigas of Mass. Corp. v. Federal Energy Regulatory Comm'n, 751 F.2d 20 (1st Cir. 1984).

15. See, e.g., Barber Lines v. Donau Maru, 764 F.2d 50 (1st Cir. 1985); Martinez v. Sea Land Servs., Inc., 763 F.2d 26 (lst Cir. 1985).

16. See, e.g., Plante v. Hobart Corp., 771 F.2d 617 (1st Cir. 1985); Lee v. El Fenix de Puerto Rico, 739 F.2d 24 (1st Cir. 1984); Laureano-Agosto v. Garcia-Caraballo, 731 F.2d 1010 (1st Cir. 1984).

17. See, e.g., Jordan v. United States Lines, Inc., 738 F.2d 48 (1st Cir. 1984); Silva v. Showcase Cinemas Concessions of Dedham, Inc., 736 F.2d 810 (1st Cir.), cert. denied, 469 U.S. 883 (1984).

18. See, e.g., Dugan v. Ramsay, 727 F.2d 192 (1 st Cir. 1984); see also Jasinskas v. Bethlehem Steel Corp., 735 F.2d 1 (lst Cir. 1984) (Worker's Comp. Board should have remanded issue to administrative law judge for factual determination).

19. I found no case in which Judge Breyer refused to follow the weight of existing judicial precedents, as he characterized them, and no case in which he set aside a factual determination made at the trial level. See, e.g., Jordan v. United States Lines, Inc., 738 F.2d 48 (1st Cir. 1984).

20. See Distrigas of Mass. Corp. v. Federal Energy Regulatory Comm'n, 737 F.2d 1208, vacated and remanded, 751 F.2d 20 (1st Cir. 1984); Distrigas of Mass. Corp. v. Boston Gas Co., 693 F.2d 1113 (1st Cir. 1982).

21. The issue in these cases is not whether the FERC can require the gas supplier to reimburse customers for past rates that were too high, which it generally cannot, but whether the agency can impose a rate structure for future charges that reduces the regulated industry's revenue below the level that had previously been authorized. If the agency finds that current rates are unreasonably high, the effect of prohibiting the FERC from reducing future rates below prevailing levels would be to retain an inefficient rate structure simply because it was approved at some time in the past. Given the many complexities and uncertainties in ratemaking regulation, it is easy to see how an agency could authorize a rate structure requested by a utility and then later might conclude on the basis of new information that the rate level is excessive.

22. See Distrigas of Mass. Corp. v. Federal Energy Regulatory Comm'n, 751 F.2d 20, 22 (1st Cir. 1984) (citing Federal Power Comm'n v. Sunray DX Oil Co., 391 U.S. 9, 21-25 (1968)); Distrigas of Mass. Corp. v. Federal Energy Regulatory Comm'n, 737 F.2d 1208, 1224 (1st Cir. 1984).

23. See Distrigas of Mass. Corp. v. Federal Energy Regulatory Comm'n, 737 F.2d 1208, 1211-14 (1st Cir. 1984). 
but his decisions were determined by statutory and Supreme Court commands that preclude an independent economic analysis. It is doubtful that any other appellate judge would have reached a contrary result on this issue.

The key point here is that economic analysis may reveal which substantive decisions are efficient, but economics provides little insight into which institutions should be responsible for making various kinds of determinations. In some instances, economic analysis could suggest the desirability of centralized decisionmaking in response to economies of scale and public goods problems, or the desirability of decentralized choices when local actors are most likely to possess required information. These economic considerations are, however, far less important than the federal governmental structure and system of checks and balances in determining the appropriate allocation of institutional responsibilities. The locus of decisionmaking authority, in contrast to the content of the decisions, is essentially an "arbitrary" choice from the perspective of economics but is frequently a critical decisional factor for judges.

\section{B. Justiciability Constraints}

This cluster of decisional factors derives from basic conceptions about the nature and limitations of judicial power, as reflected in doctrines such as mootness, ${ }^{24}$ ripeness, avoidance of advisory opinions, and compliance with class-action requirements ${ }^{25}$ or other criteria for standing. ${ }^{26}$ Although some overlap exists between this cluster of factors and the preceding one, courts may decide cases on nonjusticiability grounds even if there is no present likelihood that other institutions will resolve the particular disputes or that other parties will raise the same issues in court.

In contrast to the legal concern with justiciability, economic analysis suggests that courts should often resolve contested issues when the factual context is reasonably well developed in order to provide guidance for similarly situated actors in comparable disputes. In Berkshire Cablevision of Rhode Island, Inc. v. Burke, ${ }^{27}$ for example, Judge Breyer refused on mootness grounds to adjudicate a challenge to the legal requirement for provision of public-access channels because the plaintiff had not been awarded the franchise. This treatment leaves potential applicants in doubt about the value of cable franchises, and could therefore impede efficient competitive bidding in the future. If communities determine the suitability of competing license applications partly on the basis of the applicant's willingness to provide public-access channels, then a cable system operator who questions the

24. See, e.g., Berkshire Cablevision, Inc. v. Burke, 773 F.2d 382 (1st Cir. 1985); NLRB v. Maine Caterers, Inc., 732 F.2d 689 (1st Cir. 1984).

25. See, e.g., Mayburg v. Secretary of Health and Human Services, 740 F.2d 100 (1st Cir. 1984).

26. See, e.g., Kartell v. Blue Shield of Mass., Inc., 749 F.2d 922, 932-33 (1st Cir. 1984), cert. denied, 471 U.S. 1029 (1985).

27. 773 F.2d 382 (1st Cir. 1985). 
legality of this requirement may never obtain a franchise and be able to test its validity in court. Because cable operators frequently compete for franchises in many communities, it may be important for the particular plaintiff in the "moot" case to determine the legality of the mandated practice. Thus, from an economic perspective, the issue appears appropriate for judicial resolution whenever a current or prospective franchise applicant is motivated to raise it. A similar line of reasoning might be applied in many torts and contracts cases, where judicial clarification of the applicable law may enable more efficient loss-prevention and loss-spreading decisions by actors comparable to the parties who initially raised the issues in court. Nevertheless, Judge Breyer's refusal to address the disputed public-access requirement in Berkshire Cablevision was certainly tenable, and likely mandated, by justiciability concerns that militate against courts resolving legal issues unless they must do so.

\section{Unquantifiable and Incommensurable Interests}

A number of Judge Breyer's cases presented issues, such as free speech, ${ }^{28}$ racial discrimination, ${ }^{29}$ due process "property" rights, ${ }^{30}$ and criminal procedure, ${ }^{31}$ that are not readily amenable to economic analysis. In the essay cited above, Judge Breyer observed that "noneconomic interests" often prove influential in judicial decisions. ${ }^{32}$ In theory, any source of human satisfactions may qualify as an "economic" interest if people are willing to pay for it, ${ }^{33}$ and some "law and economics" commentators, Judge Posner and Professor Becker for example, have engaged in procrustean efforts to fit noneconomic issues into an economics framework. ${ }^{34}$ For the purposes of this paper, however, the central question is whether economic analysis can help judges decide particular cases that raise these types of issues, and I submit that economics can seldom be very useful.

An important distinction must be made between economic terminology and economic methodology. It is easy to say that interests in free speech or equal opportunity must be balanced against competing interests "at the margin," but that claim hardly qualifies as economic analysis in any meaningful sense. Some legal principles-for example, that accused criminals should be presumed innocent until proven guilty, or that government should not discriminate against people on the basis of race-derive from basic political and moral values, and would be fundamentally distorted by attempts to fit them into the utilitarian framework embedded in economic analysis. Other

28. See, e.g., Ozonoff v. Berzak, 744 F.2d 224 (1st Cir. 1984).

29. See, e.g., Sanders v. Fair, 728 F.2d 557 (1st Cir.), cert. denied, 467 U.S. 1254 (1984).

30. See, e.g., Laureano-Agosto v. Garcia-Caraballo, 731 F.2d 101 (1st Cir. 1984).

31. See, e.g., United States v. Tedeschi, 774 F.2d 511 (1st Cir. 1985); United States v. Guarino, 729 F.2d 864 (1st Cir. 1984); Cruz-Sanchez v. Rivera Cordero, 728 F.2d 1531 (1st Cir. 1984).

32. See Breyer, supra note 3 , at 296.

33. See C. Lindblom, Politics and Markets 3, 73-74 (1977); R. Posner, Economic Analysis of LAW 11-12 (2d ed. 1977).

34. See, e.g., Becker, Crime and Punishment: An Economic Approach, 76 J. Pol. Econ. 169 (1968); Posner, The Right of Privacy, 12 GA. L. REv. 393 (1978). 
interests, such as the qualified right to an unblemished reputation, may be characterized as "noneconomic" because they are extremely difficult both to quantify and compare against competing considerations. It is, of course, true that few noneconomic interests are so absolute or essential that they can never be compromised in cases that raise important countervailing principles. Yet, the resolution of such conflicts invariably requires legal judgments, not economic determinations. Unless competing interests can be approximately measured and then balanced in commensurable terms, economic methodology could not provide reliable guidance on how legal disputes should be decided. Many "law and economics" analyses of noneconomic interests substitute economic labels such as "allocative efficiency" or "utility maximization" for legal terms such as "reasonableness," but their conclusions ultimately depend upon unvalidated intuitional assessments which closely resemble the mode of legal analysis that courts have traditionally employed. Replacing one set of terms with another does not make these "law and economics" discussions any more "scientific" than conventional legal treatments.

\section{Fairness and Evenhanded Justice}

Considerations such as fairness, consistency, predictability, adequacy of notice, compliance with specified procedures, and avoidance of bias or conflict of interest also entail incommensurable noneconomic interests. These criteria, however, are primarily concerned with how the law itself should function rather than with promotion of substantive social goals. The principles underlying these decisional factors are usually difficult to define and confine in the abstract; yet, they are frequently influential in the disposition of particular cases. In Barber Lines $A / S v . M / V$ Donau Maru, for example, Judge Breyer disallowed recovery of pure economic losses partly because it might impose "disproportionate" liability in comparison with the defendant's degree of culpability. ${ }^{35}$ The New Jersey Supreme Court recently reached the opposite conclusion on the same doctrinal issue because it stressed the victim's "innocence" in comparison with the defendant's culpable behavior. ${ }^{36}$ This conflict of fairness perspectives also appears in the tension between "foreseeability" requirements and the "thin-skulled plaintiff" rule in proximate causation doctrine. ${ }^{37}$ Economic assessments provide little assistance in determining whether courts should focus on the injurer's or the victim's degree of culpability as more important in the legal analysis of which losses should be compensable. Nevertheless, most lawyers would agree that these fairness considerations should be relevant to the resolution of many cases.

35. 764 F.2d 50, 55 (lst Cir. 1985).

36. See People Express Airlines, Inc. v. Consolidated Rail Corp., 100 N.J. 246, 254-55, 495 A.2d 107, 111 (1985).

37. See generally Rabin, Tort Recovery for Negligently Inficted Economic Loss: A Reassessment, 37 STAN. L. REv. 1513,1531 n.59, 1534 n.71 (1985). 
In Itek Corporation v. First National Bank of Boston, Judge Breyer had to decide whether an American bank should honor letters of credit issued for the benefit of a government-controlled Iranian bank. ${ }^{38}$ The letters were part of a complex agreement negotiated between Itek and the Ministry of War under the Shah's regime, and the post-revolutionary Iranian government attempted to recover much of the payments made under the agreement. The contract included a force majeure clause authorizing Itek to retain payments for work completed if further compliance became impossible, ${ }^{39}$ but it also stipulated that disputes must be decided in Iranian courts applying that nation's laws. Judge Breyer acknowledged that the "very object of a letter of credit is to provide a near foolproof method of placing money in its beneficiary's hands when he complies with the terms contained in the letter itself" and that "examining the rights and wrongs of a contract dispute to determine whether a letter of credit should be paid risks depriving its beneficiary of the very advantage for which he bargained, namely that the dispute would be resolved while he is in possession of the money."40 Judge Breyer nonetheless approved an injunction forbidding payments under the letters because he thought the "recent history of relations between Iran and the United States indicates" that any efforts by Itek to recover money through the Iranian courts would be "futile."4 1

Judge Breyer rationalized this decision partly on the grounds that the beneficiary of the letters and the War Ministry "are both part of, or owned by, Iran's government, and they were equally aware of the relevant events."42 The same institutional relationship, however, existed before the revolution when Itek agreed to have disputes resolved under Iranian law, and it is doubtful that Iranian courts were any more independent of government policy under the Shah. Judge Breyer's decision ultimately rested on his view that American litigants could not obtain a fair hearing in Iranian courts, and most lawyers would similarly conclude that the need for impartial dispute resolution should override any economic analysis of contractual terms.

Criteria such as predictability, consistency, and adequate notice may frequently be efficiency enhancing because they enable private actors to make informed investment decisions. Yet, these legal criteria possess noneconomic dimensions that are probably more important than any associated efficiency effects. Conceptions that "like cases should be decided alike" and that people should not be held to legal standards they cannot possibly ascertain are central aspects of our idea of "justice." The weight given to these principles in the resolution of particular cases must be determined through legal and ethical judgments, not through economic analysis. Moreover, the factual and social contexts of disputes are never precisely "alike," and courts typically

38. 730 F.2d 19 (1st Cir. 1984).

39. Compliance became "impossible" because the U.S. Government suspended Itek's export license for the military equipment. See id. at 26.

40. Id. at 24 .

41. Id at 22 .

42. Id. at 25 . 
employ the legal skills of analogy and distinction to decide whether different cases should be treated within a common category and whether potentially applicable precedents should be followed. Any claim that this cluster of decisional factors is predominantly concerned with achievement of economically efficient outcomes would misrepresent both judicial aims and judicial methodology. As Professor Michelman has emphasized, cases may often be resolved in a fashion that apparently promotes allocative efficiency even when the promotion of efficiency is not an explicit or important ground for those decisions. ${ }^{43}$

\section{E. Global Efficiency Effects}

Proponents of microefficiency analysis, Judge Posner and Professor Coase, for example, contend that allocative decisions should be based on a balancing of competing opportunity costs in light of the individual circumstances in specific conflicts. This approach generally entails a "case-by-case" judicial cost-benefit analysis tailored to the circumstances of particular parties. In practice, however, courts are often more concerned with the effects of their decisions on broad realms of institutional or private behavior. Decisional criteria such as simplicity, uniformity, judicial economy, and administrability concerns cut against judicial assessments of individualized circumstances, and therefore frequently lead to judgments that conflict with the results suggested by microefficiency analysis. Given Judge Breyer's sensitivity to administrative considerations, his opinions predictably are filled with arguments against case-by-case dispute resolution.

In Barber Lines, Judge Breyer contended that individualized determinations of whether pure economic losses should be compensable would lead to an undesirable expansion of tort litigation, with attendant burdens on courts and litigants. 4 In Martinez v. Sea Land Services, Inc., he justified the "no fault" attribute of the warranty of seaworthiness because it would often be "all but impossible to allocate responsibility" for dangerous conditions "as between" different parties. ${ }^{45}$ In Distrigas of Massachusetts Corp. v. Federal Energy Regulatory Commission, Judge Breyer set aside the agency's decision to exclude from the ratebase certain tax benefits obtained in the period before the natural gas supplier became subject to regulation because he did not believe the FERC could reliably discriminate between "legitimate" and "illegitimate" sources of corporate assets acquired "prior to the time of regulation." 46 In New England Telephone and Telegraph Co. v. Public Utilities Commission of Maine, he refused to allow private enforcement of FCC rules on the grounds that it might interfere with creation of a nationally uniform communications policy, ${ }^{47}$ increase

43. See Michelman, Norms and Normativity in the Economic Theory of Law, 62 MINN. L. REv. 1015 (1978).

44. 764 F.2d 50, 54-55 (1st Cir. 1985).

45. 763 F.2d 26, 28 (Ist Cir. 1985) (quoting Pryor v. American President Lines, 520 F.2d 974, 981 (4th Cir. 1975)).

46. 737 F.2d 1208, 1216 (1st Cir. 1984).

47. 742 F.2d 1, 4-5 (1st Cir. 1984). 
"procedural complexity," 48 induce issue splitting between the district and circuit courts, ${ }^{49}$ and place the authority to interpret a rule's scope and meaning "squarely in the hands of private parties and some 700 federal district judges, instead of in the hands of the Commission." 50 Judge Breyer did not emphasize the individual circumstances of the litigants in any of these cases. Indeed, in response to FCC intervention on behalf of the plaintiff's position in New England Telephone $\mathcal{G}^{\circ}$ Telegraph, he observed:

\section{Perhaps such private enforcement efforts would help the FCC deal with potentially hostile state commissions in the immediate context of current telephone deregulation. but, if one steps back to ask the broader question-whether, in general, a private right to enforce FCC rules is likely to serve the Communications Act's regulatory ends-one must be more doubtful. ${ }^{51}$}

In many cases no clear boundary exists between microefficiency and global efficiency decisional criteria because judicial analyses, even if explicitly directed at the promotion of efficient market behavior, are grounded on broad generalizations about the circumstances and capabilities of different classes of actors. In Kartell $v$. Blue Shield of Massachusetts, Inc., for example, Judge Breyer reversed a district court finding that the insurer's "ban on balance billing" provision constituted an unreasonable restraint of trade. ${ }^{52}$ That practice forbids participating doctors to charge insured patients higher fees than the insurer is willing to pay for designated medical goods and services. The district court found: "[T]he effect of this payment system, when combined with Blue Shield's size and buying power, was to produce an unreasonably rigid and unjustifiably low set of prices ... [that] interferes with the doctors' freedom to set higher prices for more expensive services and discourages them from developing and offering patients more expensive (and perhaps qualitatively better) services." 53 But are prevailing prices actually "rigid" and "too low?" Must doctors participate in the Blue Shield payment system? Does the practice significantly reduce the quality and diversity of medical services? If so, are those undesirable effects outweighed by the benefits patients derive from the ban on balance billing? Judge Breyer and the lower court agreed that these questions cannot easily be answered. Indeed, the district judge described the case record as "two competing mountains of mostly meaningless papers." 54

Judge Breyer noted the "great complexity" of medical cost issues, ${ }^{55}$ and marshalled an array of policies and precedents to support allowing the insurer autonomy in its choice of payment systems. One important factor was "the possibility that patients cannot readily evaluate (as competitive buyers)

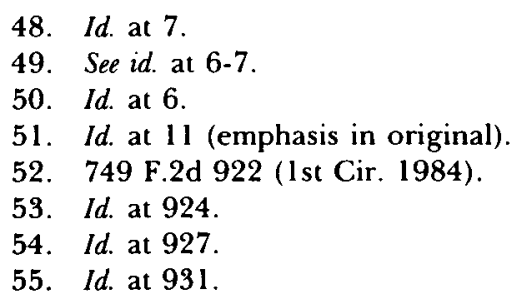


competing offers of medical service[s]." 56 Assuming the district court was justified in finding that higher prices would prevail without the disputed billing restriction, its conclusion does not resolve the critical question of whether Blue Shield's practice should be regarded as a restraint on free competition or as a corrective device to compensate for the typical patient's inability to benefit from informed, effective competition. Should the practice be characterized as a monopolistic interference with market choices or as a desirable response to information scarcity and other market imperfections?

Judge Breyer resolved this conflict in global efficiency perspectives by arguing that a "legitimate buyer is entitled to use its market power to keep prices down," 57 the Sherman Act was intended to protect "consumers against prices that were too high, not too low," 58 and "the availability of state regulation [could] prevent abuse." 59 He also contended that a "claim that Blue Shield's price scheme is 'too rigid' because it ignores qualitative differences among physicians is properly addressed to Blue Shield or to a regulator, not to a court." 60 These arguments are predominantly legal rather than economic in nature, and they all reflect Judge Breyer's intuitional belief that the lower prices result from a "legitimate" and beneficial, not "predatory" or "unreasonable," exercise of market power. ${ }^{61}$

In support of his analysis, Judge Breyer cited "a judicial recognition of the practical difficulties of determining what is a 'reasonable' or 'competitive' price."62 He also stressed his reluctance to invalidate a longstanding and widely accepted practice in the absence of clear proof that it is harmful. ${ }^{63}$ Kartell is representative of many conflicts that depend on speculative global efficiency judgments about whether markets would perform better or worse if a challenged practice is proscribed. Courts seldom possess adequate empirical data, explanatory models, and expertise to make this determination through a reliable economic analysis. ${ }^{64}$ Judges therefore tend to rely on legal characterizations and on rough intuitional predictions about which decisions will best promote underlying social policies. Even in cases where the achievement of efficient market exchanges is the primary, if not exclusive, judicial goal, considerations of administrability, predictability, or other global

56. Id. at 928 .

57. Id. at 929 .

58. Id. at 931 (emphasis in original).

59. Id. at 928 .

60. Id. at 929 .

61. Judge Breyer's contention that a buyer can generally use its market power to keep down prices is surely an overstatement. He recognized, for example, that agreements by buyers to fix prices would be unlawful. See id. at 930 . If a single agribusiness had sufficient market power to impose uncompetitively low prices on farmers, I doubt that Judge Breyer would find this practice necessarily "legitimate" even if it results in somewhat lower prices for consumers. For a theoretical critique of Judge Breyer's treatment of the monopsony issue, see Hovenkamp, Antitrust Policy After Chicago, 84 Mich. L. Rev. 213, 257-59 (1985).

62. Kartell v. Blue Shield of Mass., Inc., 749 F.2d at 927 (1st Cir. 1984), cert. denied, 471 U.S. 1029 (1985)

63. See id. at $925,928,931$

64. See, e.g., Standard Oil Co. v. United States, 337 U.S. 293 (1949). 
efficiency criteria that cannot readily be measured often prove more influential than attempts to assess the individual economic circumstances of the parties in each dispute.

In Barry Wright Corp. v. ITT Grinnell Corp. ${ }^{65}$ perhaps Judge Breyer's most influential antitrust opinion, the defendant had offered a substantial price discount to the major buyer of pipe system components used in nuclear power plants and had consequently achieved a dominant position in its particular market. ${ }^{66}$ The legal question was whether this price reduction was "predatory" and "unnecessarily excluded competition" from the market. ${ }^{67}$ Despite the particular defendant's undisputed market power, Judge Breyer created a virtual per se rule against findings of "predatory" pricing when the market price is above both marginal production costs and average production costs. ${ }^{68}$ He noted that:

[U]nlike economics, law is an administrative system the effects of which depend upon the content of rules and precedents only as they are applied by judges and juries in courts and by lawyers advising their clients. Rules that seek to embody every economic complexity and qualification may well, through the vagaries of administration, prove counter-productive, undercutting the very economic ends they seek to serve. ${ }^{69}$

Judge Breyer stressed that even legitimate price cuts may have a harmful effect on competitors, and many rivals might challenge price reductions that threaten their market share. ${ }^{70}$ Yet, preventing "a firm from unilaterally cutting its prices risks interference with one of the Sherman Act's most basic objectives: the low price levels that one would find in well-functioning competitive markets."71 Judge Breyer observed that, from the perspective of economic theory, "a price cut that leaves prices above incremental costs was probably moving prices in the 'right' direction-towards the competitive norm." 72 He also noted that when and how firms may engage in "predatory" price cutting "is all much disputed-a dispute that is not surprising given the difficulties of measuring costs, discerning intent, and predicting future market conditions." 73 In light of the complexity and uncertainty of the economic issues and the potential for high litigation costs, inconsistent results, and deterrence of desirable price reductions, Judge Breyer concluded that "this type of attack on prices that exceed both incremental and average costs would more likely interfere with the procompetitive aims of the antitrust laws than further them." 74

65. 724 F.2d 227 (1st Cir. 1983), cited in Matsushita Elec. Indus. Co. v. Zenith Radio Corp., 475 U.S. 574, 594 (1986) (Powell, J.).

66. See 724 F.2d at 229.

67. Id. at 230 (citing Greyhound Computer Corp. v. IBM, 559 F.2d 488 (9th Cir. 1977), cert. denied, 434 U.S. $1040(1978)$ ).

68. 724 F.2d at 235-36.

69. Id. at 234.

70. See id. at 235.

71. Id. at 231.

72. Id. at 232 (citations omitted).

73. Id. at 231 (citations omitted).

74. Id. at 236. 
Judge Breyer's primary arguments in ITT Grinnell did not pertain to the economic circumstances of the parties, but rather to broad global efficiency questions of administrability, consistency, and the possible effects of judicial mistakes. The Supreme Court recently cited ITT Grinnell approvingly for the general proposition that "mistaken inferences" in predatory pricing cases "are especially costly, because they chill the very conduct the antitrust laws are designed to protect. [W] must be concerned lest a rule or precedent that authorizes a search for a particular type of undesirable pricing behavior end up by discouraging legitimate price competition."75 This admonition makes clear the need for courts to consider the global economic effects of their antitrust decisions, not simply the individual circumstances of the litigants in each case. It is difficult to determine empirically whether microefficiency or global efficiency decisional criteria are, or should be, more important in the resolution of legal conflicts, but I agree with Judge Breyer that administrability and global efficiency effects must frequently be decisive considerations.

Many "law and economics" commentaries concede that "information costs," "litigation costs," or other forms of "transactions costs" may occasionally preclude case-by-case determinations based on particularized circumstances. ${ }^{76}$ Yet, these labels are only economic terminology, and their employment does not always enable meaningful economic analysis. In many contexts, there is no recognized economic methodology for determining whether the presence of "transactions costs" is sufficient to warrant legal intervention and reliance on crude but administrable legal rules, or whether voluntary market exchanges are preferable despite the presence of market imperfections. The "law and economics" literature is replete with debatable behavioral characterizations ${ }^{77}$ and guesses about the effects of legal rules on the parties' future actions. These analyses are frequently no more "scientific" than traditional judicial intuitions about global efficiency effects, fairness, or other legal considerations. Because judges must actually decide cases, not merely describe countervailing factors that might be relevant to their decisions, courts are often understandably reluctant to ground their determinations on economic analyses that cannot be comprehensive or reliable.

\section{F. Microefficiency Effects}

None of Judge Breyer's decisions clearly treated the results of conventional microeconomic analysis as outcome-determinative. The closest approximation was probably Kenworth of Boston, Inc. v. Paccar Financial Corp. ${ }^{78}$ where he held that a preliminary injunction was not warranted because the

75. Matsushita Elec. Indus. Co. v. Zenith Radio Corp., 475 U.S. 574, 594 (1986) (quoting 724 F.2d at 234).

76. See, e.g., Coase, The Problem of Social Cost, 3 J.L. \& Econ. 1,18 (1960).

77. See Latin, Problem-Solving Behavior and Theories of Tort Liability, 73 CALIF. L. REv. 677, 678-79, 682-96 \& n.46 (1985).

78. 735 F.2d 622 (1st Cir. 1984). 
plaintiff was unlikely to prevail on the merits of its antitrust claim and had not shown irreparable harm arising from the disputed practice. The plaintiff, Kenworth of Boston (KOB), sold Kenworth trucks manufactured by Paccar, and the sales were initially financed by a Paccar subsidiary. Paccar also agreed to buy back trucks purchased with its financing if a dealer became insolvent. After Paccar refused to provide further financing to KOB, the plaintiff complained that it could not acquire adequate financing from another source unless Paccar extended its buy-back arrangement to sales not financed through its subsidiary. When Paccar refused to repurchase its trucks in the event of KOB bankruptcy, the plaintiff obtained a preliminary injunction from the district court on the ostensible ground that Paccar's practice amounted to an unlawful tying arrangement. ${ }^{79}$

Judge Breyer's treatment of this case resembled a microefficiency analysis because he examined the circumstances of the particular disputants and, uncharacteristically, did not emphasize administrability, fairness, noneconomic interests, or global efficiency considerations. Nevertheless, the outcome turned more on legal characterizations than on economic analysis. He noted that in the normal "tying" context the victim must purchase one good it does not want in order to obtain a desired product. In this case, however, the defendant had unbundled its trucks, financing, and repurchase agreement, and then refused to provide anything but the trucks to KOB. Judge Breyer consequently found no unlawful tying arrangement on these facts; indeed, it was KOB, not the defendant, that wanted to link the financing and repurchasing agreement to Paccar's sale of its trucks. ${ }^{80}$ Judge Breyer also observed that, even if the repurchase guarantee had the effect of tying the trucks to the financing for those dealers who financed through Paccar's subsidiary, he could not see how KOB would be harmed by this practice because it was not required to use Paccar financing. ${ }^{81}$

From the perspective of economic analysis, the critical issue is whether there was some attribute or effect of the defendant's behavior that would impede efficient market transactions. Judge Breyer cited several economic facts that might be material to this determination, namely that Paccar produces only about eighteen percent of all heavy trucks sold, ${ }^{82}$ that Paccar provides financing and the repurchase guarantee to only about forty-five percent of the dealers selling Kenworth trucks, ${ }^{83}$ and that KOB was eventually able to obtain financing from another source despite the absence of the repurchase agreement. ${ }^{84}$ Yet, $\mathrm{KOB}$ was in the business of selling only Kenworth trucks, and undoubtedly believed its competitive position was harmed by Paccar's refusal to provide a guarantee offered to many other dealers. The economic facts cited above do not clearly establish what the

\footnotetext{
79. See id. at 623 .

80. Id. at 624 .

81. Id.

82. Id.

83. Id. at 625 .

84. Id.
} 

allocative efficiency. Once it is acknowledged that several different and frequently conflicting decisional criteria are relevant to legal dispute resolution, the courts must determine which weights should be assigned to competing considerations. The central theme in part II is that this judicial balancing of decisional criteria must itself be based on legal judgments, not on economic analysis.

The following discussion develops this theme through relatively detailed analyses of two torts issues raised in Judge Breyer's decisions. Both issues are reasonably amenable to economic analysis, which supports different conclusions from those he reached. Nevertheless, both cases present significant legal and administrability concerns that cut against economic considerations and that arguably justify Judge Breyer's decisions. The primary aim here is not to identify the "correct" resolution of these issues, but instead to demonstrate that judicial balancing of competing decisional criteria is fundamentally a legal function not determinable through economic analysis.

\section{A. Res Ipsa Loquitur and Hotel Guests}

In Lee v. El Fenix de Puerto Rico, the plaintiff was injured when a light bulb exploded on the balcony of her hotel room. ${ }^{88}$ She sued the hotel on a res ipsa loquitur rationale, and the district court granted the defendant's motion for summary judgment. In a brief opinion, Judge Breyer affirmed the lower court's action on the following grounds:

Puerto Rico courts do not apply the doctrine of res ipsa loquitur if the likely negligent act occurred at a time when the object in question was outside the defendant's exclusive control. And the doctrine does not operate if there is a "probable cause" of the accident from which it could be inferred that the defendant was not negligent. Here, the district court could readily reason that a light bulb that explodes is likely defective and that the likely cause of the defect lies in its manufacture, not its use. If so, the negligent act occurred when the bulb was manufactured, that is to say, when it was outside the hotel's control. Thus, the court correctly concluded that under the law of Puerto Rico, res ipsa loquitur does not apply. ${ }^{89}$

The central issues in this case are (1) whether the injured guest or the hotel should be required to identify the bulb's manufacturer; (2) whether the hotel or victim should bear the losses if the manufacturer cannot be identified or joined in the suit; and (3) whether the hotel or guest should bear the losses if the producer succeeds in showing that the explosion probably did not result from a manufacturing defect. From the perspective of economic analysis, or fairness for that matter, it is difficult to imagine how these issues could be resolved in the hotel's favor.

Guests at hotels cannot be expected to compile a list of the equipment furnished in their rooms and of the product manufacturers, nor would it be efficient for each guest to do so if she could. The hotel, on the other hand, purchases the equipment and could easily maintain records on its suppliers

88. 739 F.2d 24 (1st Cir. 1984).

89. Id. at 25 (citations omitted). 
and where their products were installed. Moreover, an exploding light bulb is likely to be destroyed in the explosion, which means the injured guest may not be able to determine the manufacturer's identity after the accident without the hotel's assistance. The hotel staff would generally be better able to collect whatever post-accident evidence is available because the victim will frequently be preoccupied by her injuries. Judge Breyer's treatment creates a positive disincentive for hotels to keep precise records on their suppliers: if the hotel identifies the manufacturer, it runs some risk that a jury may believe the accident resulted from improper handling by its employees rather than from a manufacturing defect. If the hotel does not disclose the manufacturer's identity, however, the presumption of Judge Breyer and the district judge that the injury resulted from a manufacturing defect would insulate the hotel from liability.

Another economic consideration is that the hotel may be encouraged to purchase cheap but comparatively unsafe products if it ordinarily will not be liable for injuries resulting from unexplained product failures. Clearly, the hotel is much better able than guests to assess the reliability of products offered by competing suppliers, and there is no reason why guests should unknowingly be put at risk when the hotel chooses less expensive but less safe equipment. The same logic would apply when the hotel selects a supplier that is judgment-proof or cannot readily be sued in the jurisdiction where the injury may occur. This set of arguments is not especially compelling because hotels have strong nonlegal motivations to avoid injuring their customers. ${ }^{90}$ Nevertheless, applying res ipsa loquitur to hotels in this accident context would create some marginal deterrent incentive, while Judge Breyer's treatment creates a disincentive, however minimal, for hotels to exercise care in the choice of their equipment and affords no compensating increase in the propensity of guests to protect themselves. The traditionally high duty of care imposed on innkeepers reflects a realistic policy judgment that customers rely on hotels to provide safe premises and that hotels encourage this reliance.

It also appears unlikely that Judge Breyer's treatment will significantly reduce private litigation costs or promote judicial economy. He did not explain how he concluded that light bulb explosions usually result from manufacturing defects, but the manufacturer is very likely to argue that the accident was caused by mishandling, improper installation, or product damage after the bulb left its control. If this supposition is correct, the hotel will typically be joined as a codefendant after the manufacturer is sued. The only "judicial economy" would occur in cases where the plaintiff is unable to identify the manufacturer and therefore is left without any remedy, but Judge Breyer's analysis did not seem to contemplate or approve that circumstance.

90. I have argued that torts analysts should not simply assume that liability will always induce significant accident-avoidance behavior. In some cases, actors do not understand or pay attention to applicable liability rules, and in other circumstances nonlegal incentives are a much more powerful determinant of behavior than are liability doctrines. See Latin, supra note 77, at 686-92. 
Moreover, in cases where the manufacturer is sued and is able to prove the accident probably was not caused by a manufacturing defect, res ipsa loquitur would almost certainly be applied against the hotel at that point. If "a light bulb that explodes is likely defective," as Judge Breyer observed in the passage quoted above, and if the manufacturer is found not responsible for that defect, then the hotel is likely to be the responsible party. Thus, the effect of allowing the plaintiff to sue the hotel initially on res ipsa loquitur grounds would be to encourage the hotel to identify the product manufacturer, without expanding the scope of litigation in most cases.

This analysis would not preclude application of res ipsa loquitur against a product manufacturer when it can be identified, and many cases, most notably Escola v. Coca-Cola Bottling Co., ${ }^{91}$ have relied on the doctrine in factual contexts similar to the one presented in Lee. At least in recent years, these decisions have not rested on assertions that a manufacturing defect is necessarily the most likely cause or that the manufacturer had "exclusive" control of the product. Rather, the application of res ipsa loquitur may be justified on a variety of policy grounds, including deterrence, reliance, the likelihood that material evidence will be destroyed in the accident, the frequent inability of victims to establish the precise cause, the superior access of manufacturers to relevant information and expertise, simplification of the judicial fact-finding process, and the producer's ability to spread losses through enterprise liability. ${ }^{92}$ These considerations may be persuasive when the positions of product users and manufacturers are contrasted, but they do not indicate that res ipsa loquitur should be applied only to the manufacturer.

In cases such as Ybarra $v$. Spangard, ${ }^{93}$ courts have allowed plaintiffs to use the doctrine against several independent defendants when uncertainty about which one is responsible might otherwise prevent recovery for a clearly compensable injury, and when the circumstances induce potential victims to rely on those defendants for protection and for information about how the accident occurred. The plaintiff's position in Lee meets all of these criteria. In the absence of any claim of contributory negligence, the victim of an exploding light bulb in a hotel room should be able to recover either from the manufacturer or hotel. Uncertainty about the cause of the defect or about the manufacturer's identity should not enable both possible defendants to escape liability.

91. 24 Cal. 2d 453, 150 P.2d 436 (1944).

92. See, e.g., Halloran v. Virginia Chems., Inc., 41 N.Y.2d 386, 361 N.E.2d 991,393 N.Y.S.2d 341 (1977); Jagmin v. Simonds Abrasive Co., 61 Wis. 2d 60, 211 N.W.2d 810 (1973). These policies are, of course, the same ones cited by Justice Traynor in his famous concurring opinion in Escola, and they are similarly applicable in the res ipsa loquitur context. In both strict products liability and res ipsa loquitur cases, injured plaintiffs frequently cannot identify the precise defect or show that it existed at the time the manufacturer placed the product in the stream of commerce because the product has been destroyed by the explosion. Thus, the inability to couple strict products liability doctrines with res ipsa loquitur would often defeat recovery in the very type of accident presented in Escola.

93. 25 Cal. 2d 486, 154 P.2d 687 (1944), aff'd, 93 Cal. App. 2d 43, 208 P.2d 445 (1949). 
Even if all economic, fairness, and social policy considerations suggest that this treatment would make "good law," the problem for federal judges is that it may not represent the current law in Puerto Rico. To support his conclusion that the jurisdiction does not allow res ipsa loquitur to be used against one defendant when another actor is the "likely" cause, Judge Breyer cited precedents from 1953, 1954, and 1963.94 These decisions largely predate the application of economic analysis to legal issues and also predate the development of modern products liability law. Assuming, however, that Judge Breyer and the district court judge correctly characterized the doctrine of res ipsa loquitur in Puerto Rican law, it is difficult to see how any form of economic analysis could negate the obligation of federal courts to follow the law of the jurisdiction in which the accident occurred. When important issues pertaining to allocation of institutional responsibilities are raised in a case, judges generally cannot balance those concerns against the economic effects of their decisions. Thus, institutional considerations may often dominate the other decisional criteria, while it is doubtful that the results of economic analysis can ever outweigh significant limitations on the decisionmaking authority of the federal courts.

\section{B. Compensation for Pure Economic Losses}

The issue of whether a negligent actor must provide compensation for economic losses without accompanying physical injury or property damage arises in a variety of accident contexts, ${ }^{95}$ but this discussion will largely be confined to three 1985 cases that involved the commercial transportation of oil and hazardous substances. In Barber Lines, Judge Breyer adopted the traditional rule that denies recovery for economic losses except in a few limited circumstances which he thought inapplicable. ${ }^{96}$ In Louisiana ex rel. Guste v. $M / V$ Testbank, a majority of the Fifth Circuit sitting en banc applied the traditional rule to all economic victims of a toxic spill except commercial fisherman whose income was affected; 97 but five judges joined in dissenting opinions that argued for a broader scope of recovery. ${ }^{98}$ In People Express Airlines, Inc. v. Consolidated Rail Corp., the New Jersey Supreme Court unanimously rejected the traditional prohibition in favor of a more permissive "particular foreseeability" test. 99 These conflicting judicial treatments reveal

94. Lee v. El Fenix de Puerto Rico, 739 F.2d 24, 25 (1st Cir. 1984). I did not investigate Puerto Rican law because the purpose of this paper is to analyze the economic arguments presented in the text, rather than to determine whether each case was correctly decided on legal grounds. For purposes of this discussion, I assumed that Judge Breyer correctly interpreted the law.

95. See generally Rabin, supra note 37.

96. Barber Lines v. Donau Maru, 764 F.2d 50, 56 (1st Cir. 1985).

97. 752 F.2d 1019 (5th Cir. 1985) (Higginbotham, J.), cert. denied sub. nom. White v. M/V Testbank, 477 U.S. 903 (1986); id. at 1034 (Williams, J., concurring); id. at 1034-35 (Garwood, J., concurring). The treatment of commercial fishermen was not before the appellate court, but the district judge had allowed that class of victims to recover economic losses and several appellate judges intimated that they approved this result. See id. at $1021,1034,1053$.

98. Id. at 1035 (Wisdom, J., dissenting); id at 1053 (Rubin, J., dissenting).

99. 100 N.J. 246, 262-68, 495 A.2d 107, 115-18 (1985). 
that the issue of pure economic losses raises a panoply of relevant decisional criteria, with no single factor likely to be determinative. Thus, unlike in Lee, courts must really balance competing considerations to decide the scope of compensable economic damages.

The plaintiffs in Barber Lines incurred significant additional expenses when an oil spill prevented their vessel from docking at its intended berth. The district court dismissed their complaint on the grounds that economic losses are not compensable without damage to the ship, and the court of appeals affirmed that decision. Judge Breyer emphasized the many precedents supporting this treatment, especially the leading Supreme Court decision in Robins Dry Dock and the Second Circuit decision in Kinsman II. ${ }^{100}$ He also identified a number of administrability, fairness, and global efficiency considerations that supported his reliance on those precedents. Judge Breyer argued that allowing recovery for all foreseeable economic losses would greatly increase the number of claims and the cumulative costs of litigation; ${ }^{101}$ that it might impose disproportionate liability on defendants in comparison with their fault; ${ }^{102}$ that it might create perverse investment incentives because actors may not be able to prevent or insure against potentially unlimited liability; ${ }^{103}$ that prospective victims might often be better able to insure themselves against interferences with their commercial expectations; ${ }^{104}$ that allowing recovery of economic losses only when combined with physical injury or property damage would confine the volume of litigation and yet would frequently create sufficient deterrent incentives to avoid negligent behavior; ${ }^{105}$ and that courts could seldom make principled distinctions among categories of economic losses or classes of plaintiffs once they approve this form of recovery in the abstract. ${ }^{106}$

Judge Breyer acknowledged that many cases have allowed recovery for economic losses, and he attempted to identify special circumstances in which exceptions have been authorized. These include the presence of intentionally caused harm, defamation or injurious falsehood, negligent misrepresentations about financial matters, loss of consortium, expenses on family members or employers, and treatment of commercial fishermen as "favorites of admiralty." 107 He then continued: "These exceptions seem designed to pick out broad catagories of cases where the 'administrative' and 'disproportionality' problems intuitively seem insignificant or where some strong countervailing consideration militates in favor of liability." 108 For

100. Barber Lines v. Donau Maru, 764 F.2d 60, $51-53$ (1st Cir. 1985) (citing Robins Dry Dock \& Repair Co. v. Flint, 275 U.S. 303 (1927)); Petition of Kinsman Transit Co., 388 F.2d 821 (2d Cir. 1968)).

101. See Barber Lines, 764 F.2d at 54.

102. See id. at 55.

103. See id.

104. See id. at 54.

105. See id. at 55-56

106. See id. at 52, 56-57.

107. See id. at 56.

108. Id. 
example, Judge Breyer noted that compensation for economic losses caused by misstatements of financial data is justified because "without such liability, tort law would not exert significant financial pressure to avoid negligence; a negligent accountant lacks physically harmed victims as potential plaintiffs." 109 This exception has also been justified on the ground that the public relies on the accuracy of financial disclosures. ${ }^{110}$ Yet, imposing liability on accountants or lawyers for negligent misrepresentations raises the same problems of high litigation costs, "disproportionate" liability, and judicial difficulty in determining where liability should be cut off that Judge Breyer found dispositive in Barber Lines. He must therefore have concluded that deterrence and reliance interests may outweigh fairness, administrability, and global efficiency considerations in the context of economic losses resulting from negligent misrepresentations but not from oil spills.

Despite Judge Breyer's observation that "strong countervailing" policies could militate in favor of liability, ${ }^{11}$ he devoted little analysis to whether the particular circumstances associated with oil spills might merit exceptional treatment. He instead borrowed from Kinsman II the analogy of a motorist who negligently obstructs a tunnel, and then discussed the potentially unbounded liability for economic losses that could result from oil spills or tunnel accidents. ${ }^{112}$ This generalized analysis comports with a recurring theme in his opinion that judges should not make economic loss determinations on a case-by-case basis. ${ }^{113}$ He contended, for example, that:

[C]onsiderations "of administrability and disproportionality" offer plausible, though highly abstract, "policy" support for the reluctance of the courts to impose tort liability for purely financial harm. While they seem unlikely to apply with equal strength to every sort of "financial harm" claim, their abstraction and generality, along with the comparative inaccessibility of the empirical information needed to confirm or invalidate them, mean that courts cannot weigh or apply them case by case. What, for example, in cases like this one, are the added administrative costs involved in allowing all persons suffering pure financial harm to sue the shipowner. . . . Is there a problem of "disproportionality"? How far . . . [would] liability for negligently caused oil spills, when added to the already large potential traditional liability, affect the type of insurance carried, the incentive to mitigate losses, the incentive to transport oil safely, the likelihood that shippers will use pipelines and domestic wells instead of ships and foreign wells, and the consequences of these and other related changes? We do not know the answers to these questions, nor can judges readily answer them in particular cases. 114

Yet, many similar imponderables would complicate judicial analyses in misrepresentation, defamation, and physical injury cases where economic losses are compensable. Administrability concerns and fear of unbounded or disproportionate liability are undoubtedly important considerations, but they do not explain all judicial treatments of economic losses and may be outweighed in some accident contexts by competing criteria. Judge Breyer

109. Id.

110. See Rabin, supra note 37 , at 1528.

111. Barber Lines, 764 F.2d at 56 .

112. See id. at 52,57 .

113. See id. at 53-57.

114. Id. at 55. 
correctly argued that courts must "consider exceptions by class rather than case by case," 115 but he did not discuss how classes may be distinguished and how broadly or narrowly they should be defined. He also did not consider in detail whether economic losses resulting from oil spills should be treated as a distinct class of cases, at least with respect to some categories of potential victims. Rather, his analysis of this accident context treated "unbounded liability" and "no liability" as the only realistic alternatives.

The plaintiff in People Express Airlines suffered business-interruption losses when a spill of ethylene oxide, a potentially explosive chemical, in a railroad freight yard required evacuation of the surrounding area including the airlines terminal. ${ }^{116}$ The plaintiff's property was not physically damaged because the chemical spill fortuitously did not produce an explosion. In addressing the economic losses issue, Justice Handler cited many of the same conflicting precedents and policies enumerated by Judge Breyer. The New Jersey Supreme Court, however, emphasized that "the overarching purpose of tort law" is to ensure "that wronged persons should be compensated for their injuries and that those responsible for the wrong should bear the cost of their tortious conduct." 117 Aside from this "fairness" perspective, Justice Handler stressed the deterrence objective of imposing liability on parties who can prevent accidents and "are best able to bear" the cost of dangerous activities. ${ }^{118}$ He recognized the administrability problems presented by this issue and the judicial difficulty in drawing consistent lines to distinguish compensable economic losses from unrecoverable damages, 119 but he nonetheless held that " $[t]$ he asserted inability to fix chrystalline formulae for recovery on the differing facts of future cases simply does not justify the wholesale rejection of recovery in all cases." 120 In support of this conclusion, Justice Handler reviewed many of the precedents allowing compensation and argued that these "exceptions expose the hopeless artificiality of the per se rule against recovery for purely economic losses."121

Justice Handler identified several factors that he thought would prevent imposition of unlimited liability, including the proximate causation tests for remoteness and intervening causes, ${ }^{122}$ the plaintiff's "difficult task" in proving expectation damages with a sufficient degree of certainty, ${ }^{123}$ and the requirement for particular foreseeability with respect to the class of plaintiffs and the type of economic losses. ${ }^{124}$ The court described this particular foreseeability test "in terms of the type of persons or entities comprising the

115. Id. at 56.

116. See People Express Airlines, Inc. v. Consolidated Rail Corp., 100 N.J. 246, 249, 495 A.2d 107,108 (1985).

117. Id. at $255,495 \mathrm{~A} .2 \mathrm{~d}$ at 111 .

118. Id.

119. See id. at 252, 254, 263-64, 266, 495 A.2d at 110, $111,115-17$.

120. Id. at 254,495 A.2d at 111 .

121. Id. at $261,495 \mathrm{~A} .2 \mathrm{~d}$ at 114 .

122. See id. at $252-253,265,495$ A.2d at $110,117$.

123. Id. at 268,495 A.2d at 118 .

124. See id. at 262-64, 495 A.2d at 115-16. 
class, the certainty or predictability of their presence, the approximate numbers of those in the class, as well as the type of economic expectations disrupted."'125 Justice Handler contended that this requirement was consistent with a general principle abstracted from the precedents on economic losses "that the extent of liability and degree of foreseeability stand in direct proportion to one another."126 He acknowledged that some cases will "defy" categorization based on particular foreseeability, and argued that courts in those cases must "draw upon notions of fairness, common sense, and morality to fix the line limiting liability as a matter of public policy."127 These somewhat ethereal criteria obviously leave more room for judicial speculation and inconsistency than Judge Breyer would find appropriate, but these criteria also are less likely to prevent "innocent" plaintiffs from obtaining compensation for readily foreseeable losses. ${ }^{128}$

Justice Handler held that the facts alleged by the plaintiff were sufficient to establish a tenable claim of particular foreseeability. Pertinent factors included "the close proximity of the North terminal and People Express Airlines to the Conrail freight yard; the obvious nature of the plaintiff's operations and particular foreseeability of economic losses resulting from an accident and evacuation; the defendants' actual or constructive knowledge of the volatile properties of ethylene oxide; and the existence of an emergency response plan prepared by some of the defendants . . . which apparently called for the nearby area to be evacuated to avoid the risk of harm in case of an explosion."129 This emphasis on the specific circumstances of the parties clearly indicates that a particular foreseeability test must be applied on a caseby-case basis, and the New Jersey Supreme Court explicitly concluded that the doctrine should "be allowed to evolve" in the context of individual adjudications. ${ }^{130}$ Thus, the opinions in Barber Lines and People Express Airlines not only assigned different weights to competing decisional criteria, but they advocated resolution of the economic losses issue through fundamentally different adjudicative processes.

As a result of collision with another vessel, the defendant's ship in Testbank spilled twelve tons of a highly toxic chemical that temporarily contaminated about 400 square miles of waterways and coastal areas in the Mississippi River Gulf. ${ }^{131}$ The Fifth Circuit Court of Appeals affirmed summary judgments against all economic loss claimants who did not allege physical injury or property damage, except for commercial fishermen in the region. The majority, concurring, and dissenting opinions raised many of the legal arguments and conflicting policy considerations described above, but it would

125. Id. at $264,495 \mathrm{~A} .2 \mathrm{~d}$ at 116 .

126. Id. at 263, $495 \mathrm{~A} .2 \mathrm{~d}$ at 115-16.

127. Id. at $264,495 \mathrm{~A} .2 \mathrm{~d}$ at 116.

128. Id. at 254, $495 \mathrm{~A} .2 \mathrm{~d}$ at 111 ; see supra text accompanying notes 35-36.

129. Id. at $267-68,495 \mathrm{~A} .2 \mathrm{~d}$ at 118 .

130. Id. at 268,495 A.2d at 118 .

131. Louisiana ex rel. Guste v. M/V Testbank, 752 F.2d 1019, 1020 (5th Cir. 1985), cert. denied sub. nom. White v. M/V Testbank, 477 U.S. 903 (1986). 
serve little purpose to repeat them here. There were, however, a few salient points worth discussion. Aside from administrability concerns, Judge Higginbotham's majority opinion stressed the need for a "determinable rule of law" that would enable courts to reach predictable and consistent decisions. ${ }^{132}$ He conceded that a "bright line rule" of damages "has the virtue of predictability with the vice of creating results in cases at its edge that are said to be 'unjust' or 'unfair,'"133 but he countered that "when lines are drawn sufficiently sharp in their definitional edges to be reasonable and predictable, such differing results are the inevitable result-indeed, decisions are the desired product."134 In contrast, Judge Wisdom's dissenting opinion advocated reliance on individualized considerations of foreseeability, proximate cause, and particularity of the damages suffered by each category of plaintiffs. ${ }^{135}$

Appeals to the legal values of predictability and consistency always have some allure, but Judge Higginbotham did not explain why they are persuasive in this accident context. If a victim suffers physical harm as well as economic losses, the court's treatment would authorize recovery of both types of damages. Yet, the plaintiff in such a case would still have to establish the presence of negligence and legal causation. The negligence test of "reasonable care under all the circumstances" does not create a bright line liability rule. The "remoteness" and "foreseeability" elements in the proximate causation test must also be evaluated based on particularized circumstances. Judge Garwood wrote in a concurring opinion that he especially agreed with Judge Higginbotham's emphasis on the need "for distinguishing, on a normative, pre-event basis, between the classes of cases in which recovery will be allowed and those in which it will not."136 Neither judge, however, indicated why predictability is more important for a damages test than for liability and proximate causation requirements. ${ }^{137}$

132. Id. at 1028 .

133. Id. at 1029 .

134. Id.

135. See id. at $1039,1042-43,1046-59$. The proposed requirement of "particular damages" is essentially the same as the test for recovery in a public nuisance suit.

136. Id. at 1035 .

137. In the event of a widespread spill of oil or toxic substances, some physical harm is very likely and its extent would depend on numerous factors outside the control or knowledge of the defendant. The bright line rule will not provide useful guidance for potential defendants unless they can predict, which in practice they frequently cannot, whether foreseeable economic losses will be associated with physical harm that renders both types of damages compensable under the court's treatment. Although Judge Higginbotham, like Judge Breyer, noted that victims may sometimes be able to insure themselves against economic loss, see id. at 1029, the bright line rule also will not necessarily lead to efficient levels of insurance because potential plaintiffs often cannot anticipate whether their economic losses will accompany sufficient physical damage to enable recovery for both. Thus, the actual impact of the bright line rule on the parties would not be very predictable. I therefore regard administrability concerns as far more persuasive in this accident context than are global efficiency arguments grounded on the supposed value of predictability. It also seems relevant that inconsistencies resulting from individualized considerations of factual circumstances under the negligence and proximate causation test have seldom justified adoption of bright line liability and causation rules. 
With respect to marginal deterrence effects, Judge Higginbotham observed:

[W] agree with plaintiffs that economic analysis, even at the rudimentary level of jurists, is helpful. . . . Thus it is suggested that placing all the consequences of its error on the maritime industry will enhance its incentive for safety. While correct, as far as such analysis goes, such in terrorem benefits have an optimal level. Presumably, when the cost of an unsafe condition exceeds its utility there is an incentive to change. As the costs of an accident become increasing multiples of its utility, however, there is a point at which greater accident costs lose meaning, and the incentives curve flattens. When the accident costs are added in large but unknowable amounts the value of the exercise is diminished. ${ }^{138}$

When an actor's behavior is extemely inefficient, in the sense that resulting accident costs far outweigh its benefits, this imbalance has rarely been regarded by courts as an argument against the imposition of liability. The critical deterrence question is whether the extent of liability is sufficiently great that further liability would not create a significant marginal incentive for accident prevention. Judge Breyer contended that recovery of economic losses associated with physical damage would create "enough" deterrence in the context of oil spills, but he recognized that the opposite conclusion may apply for negligent misrepresentations of financial matters. Judge Higginbotham similarly hypothesized that: " $[w]$ ith a disaster inflicting large and reverberating injuries through the economy, as here, we believe the more important economic inquiry is that of relative cost of administration, and in maritime matters administration quickly involves insurance." 139 He predicted that the plaintiff's proposed rule change would "work a shift to the more costly liability system of third party insurance." 140 Judge Higginbotham's characterization of relative insurance costs is debatable because toxic shippers must in any event obtain insurance to cover infliction of physical harm with associated economic losses, and there are likely to be fewer shippers, with lower insurance transactions costs, than potential victims. In other words, both shippers and prospective victims must insure themselves under the court's supposed bright line rule. Judge Higginbotham's claim that administrative cost considerations outweigh marginal deterrence concerns is even more speculative in this accident context. One might argue in the alternative that the great potential for harm associated with transportation of oil and toxic substances justifies legal imposition of comparably great incentives for accident prevention.

The adoption of economic terminology and concepts does not necessarily enable judges to perform meaningful economic analyses. Courts generally lack the empirical information and expertise needed to balance competing global efficiency considerations such as marginal deterrence effects and administrative costs in a reliable manner. They must therefore either rely on crude intuitions or eliminate analysis of these criteria altogether. To the

138. Id.

139. Id.

140. Id. 
extent marginal deterrence is regarded as an important consideration, as it should be in oil and toxic spill cases, ${ }^{141}$ economic analysis suggests that a single bright line rule against recovery of economic losses is likely to be undesirable. Rather, decisions about compensability should be tailored to the characteristic circumstances of different categories of accident contexts. A judicial assessment of when the deterrent incentives curve has flattened, to use Judge Higginbotham's phrase, clearly cannot be made once for all modes of risky behavior.

In Union Oil Co. v. Oppen, ${ }^{142}$ another oil spill case, Judge Sneed of the Ninth Circuit Court of Appeals unsuccessfully tried to apply Dean Calabresi's economic analysis framework. Judge Sneed noted that "we have no way of evaluating the relative administrative costs involved," but he nonetheless concluded that the determinative consideration was the defendant's ability to "correct any error in allocation, if such there be, by acquiring the activity to which the party has been made liable." 143 Judge Posner criticized the Oppen decision as an "abuse" of economic analysis because "it is improbable that the correct solution to the problem of oil spills is to merge the commercial fishing industry and the oil industry into one giant firm."144 Judge Posner cited Oppen as an instance where a court reached the economically correct result even when the judge did not explicitly adopt or understand economic analysis. ${ }^{145}$ Yet, Judge Posner's explanation of why the defendants should be liable for economic losses may be little better than Judge Sneed's analysis. Judge Posner argued that :

[The court's] conclusion that the oil companies should be liable for the loss to the commercial fisherman even though the fishermen had no property right in fish they had not yet caught seems correct as a matter of economics: only the oil companies can take efficient measures to prevent or limit oil damage to the fish, and making them liable to the fishermen will give the oil companies the correct incentives to take those measures. But Judge Sneed's effort to articulate his reasoning in economic terms was disastrous. ${ }^{146}$

Any time a defendant is found negligent, that represents a judicial determination that he should have taken measures to prevent the accident. Judge Posner's argument is entirely unhelpful in deciding which negligently inflicted economic losses should be compensable and which should not be, the central issue in Barber Lines, Oppen, and a host of similar cases. The best that could be said for his analysis is that it suggests defendants should always be liable for all losses resulting from their negligent conduct, but that thesis completely ignores "unbounded liability," "disproportionality," and "judicial economy" considerations. Moreover, factors such as insurance costs, litigation costs, and other administrative considerations are clearly relevant to the economically correct treatment of oil pollution losses, but Judge Posner

141. See infra text accompanying notes 147-50.

142. 501 F.2d 558 (9th Cir. 1974).

143. $I d$. at $569-70$.

144. Posner, Some Uses and Abuses of Economics in Law, 46 U. CHI. L. Rev. 281, 300 (1979).

145. See id. at 300-01.

146. Id. at 300 . 
ignored these global efficiency concerns and provided no hint of how they could be estimated or balanced against deterrence considerations in particular disputes. And, even from the perspective of microefficiency effects, it is not obviously true that only oil companies can prevent these economic losses. Professor Coase's famous analysis of social costs suggests that it might be more efficient for the fishermen to move away in order to reduce their risk of lost income from oil pollution. ${ }^{147}$ Judge Sneed fastened on one economic concept of doubtful utility in Oppen while identifying others that he thought inapplicable or beyond his ability to calculate. Judge Posner fastened on one relevant, but not necessarily decisive, economic concept while ignoring many other economic and noneconomic considerations. His simplistic analysis clearly does not support his conclusion that the case was rightly decided from an economic viewpoint, and it is even less able to support his claim that economic analysis should be a primary basis for judicial determinations.

Several important considerations cut against a bright line rule prohibiting recovery of pure economic losses in oil and toxic spill cases. First, much of the resulting physical damage will not be internalized through successful tort suits. Spills of harmful substances frequently degrade environmental resources-wetlands ecosystems, endangered species, or scenic vistas, for example-that contribute to social welfare but are not "owned" in a sufficiently concrete manner to support a claim for compensation. Spills also have long term harmful effects that cannot be established in court with a sufficient degree of certainty to meet legal causation requirements. For example, even when fishermen in a case like Oppen or Testbank are allowed to recover their immediate financial losses, there is little chance that they would receive compensation if the fish population declines over time in response to ecological stresses produced by a spill. In the same vein, we know that exposures to toxic substances often create a potential for harmful health effects, but long latency periods and other causal problems preclude some affected individuals from obtaining compensation. Moreover, spills frequently entail widespread effects that create relatively minor property damage or health problems for large numbers of people; but the costs and inconvenience of litigation may prevent many injured parties from suing for compensation. In these cases, the physical harm for each affected person may be small, but the cumulative social impacts can be substantial. Thus, from the perspective of deterrent incentives, recovery of pure economic losses by some categories of plaintiffs may serve as a partial surrogate for theoretically compensable physical harms that are unlikely to be internalized through tort suits.

Second, unlike in the case of the tunnel-obstruction analogy used in Barber Lines and Kinsman II, parties responsible for oil and toxic spills generally choose a scale of operations that creates an obvious risk of widespread physical and economic harm if accidents occur. A few decades ago, oil was

147. See Coase, supra note 76. 
shipped in small tankers and processed in relatively small refineries; but to achieve economies of scale, the industry now employs supertankers and large processing plants. Only a few toxic substances were in wide use before 1950 , but there are now hundreds, more likely thousands, that have been introduced on cost-effectiveness and convenience grounds, and the quantities of these substances have increased exponentially. This observation does not suggest that these industrial decisions were either inefficient or morally wrong, but they have greatly increased the chances of spills with serious physical and economic effects for many segments of society. If private decisions to increase the scale of operations and corresponding economic (as well as physical) risks are justified on cost-effectiveness grounds, then it does not seem unreasonable to require these activities to bear a greater portion of the resulting economic losses than they do under the traditional rule. As Justice Handler argued, ${ }^{148}$ a defendant's actual or constructive knowledge of the magnitude of risks created for particular classes of victims appears relevant to the question of what level of liability is "disproportionate."

Third, current liability and damages doctrines apparently do not create sufficient deterrent incentives in many spill contexts. There have been numerous instances in which tankers are poorly operated or maintained, in which crews are inadequately trained, in which toxic shipments have been routed through urban or ecologically sensitive areas in order to save a few hours of transit time, in which toxic shippers and producers have failed to develop adequate contingency plans to deal with spills, and in which available safety measures were not implemented until after potential disasters occurred, if at all. These problems have led to increased federal and state regulation, but those programs were not intended to preempt tort liability and thus far have not clearly proven effective. It seems anomalous that courts have recently increased the scope of theoretical liability for these activities through application of a variety of strict liability doctrines, ${ }^{149}$ but most judges continue to cling tenaciously to restrictive damages doctrines that dilute the practical significance of these doctrinal changes.

Finally, allowing some categories of plaintiffs to recover pure economic losses will not inevitably lead to unbounded liability. Shippers usually plan their routes with care, and there is no reason why they cannot at least generally identify some types of parties-for example, other shippers, resort owners, owners of factories immediately adjacent to a railroad right of way, and commercial fishermen-who are likely to be harmed by a spill. Such judgments may have an undesirable ad hoc quality and cannot be perfectly consistent, as Judge Breyer observed about Judge Wisdom's dissenting analysis in Testbank. ${ }^{150}$ But the traditional rule is not applied in a perfectly

148. See People Express Airlines, Inc. v. Consol. Rail Corp., 100 N.J. 246, 256, 262-63, 495 A.2d $107,112,115-16$ (1985).

149. See, e.g., State Dep't of Env'l Protection v. Ventron Corp., 94 N.J. 473, 468 A.2d 150 (1983); Siegler v. Kuhlman, 81 Wash. 2d 448, 502 P.2d 1181 (1972), cert. denied, 411 U.S. 983 (1973).

150. See Barber Lines v. Donau Maru, 764 F.2d 50, 57 (1st Cir. 1985). 
consistent manner either, and the distinction grounded on the presence or absence of minimal physical harm is no less arbitrary in application than a "particular foreseeability" test of the sort advocated by Justice Handler. This analysis, however, has been tailored to the general circumstances of oil and toxic spills. A particular foreseeability test would not be appropriate or feasible in every accident context, and judicial determinations about which losses are compensable should be made on a categorical, not case-by-case, basis.

In summation, I disagree with Judge Breyer's treatment of economic losses for three primary reasons: based on the predictable severity of harm associated with oil and toxic spills but not tunnel obstructions, the creation of effective accident-prevention incentives is especially important in this cuntext; his contention that liability for economic losses accompanying physical damage may create "sufficient" deterrence is implausible in this accident setting; and, while administrability and "unbounded liability" are important concerns in spill cases, they do not outweigh deterrence considerations to the extent that recovery should be barred for all classes of foreseeably injured plaintiffs. These conclusions fall at least loosely within the bounds of economic analysis, although they are grounded on intuitions about globalefficiency effects rather than on any formal economic methodology. Nevertheless, Judge Breyer identified numerous difficulties with judicial implementation of a relatively particularized treatment of economic losses, and the weights he assigned to competing considerations cannot be characterized as clearly "wrong."

The central theme in this discussion of pure economic damages is that many decisional criteria will influence judicial determinations. Judges must evaluate conflicting predictions about deterrence incentives, about administrative costs, about the breadth of litigation likely to result from alternative doctrinal treatments, and about the long term impacts of judicial decisions on the investment strategies and behavior of different classes of actors. In addition to these microefficiency and global efficiency effects, judges must consider conflicting "fairness" and "proportionality" arguments, conflicting case precedents, and conflicting assessments of the need for consistency and predictability in varied accident contexts. It seems most improbable that any unidimensional criterion, such as the promotion of economic efficiency, could be determinative in all cases even if judges could reliably ascertain the precise value of each relevant factor. And, in reality, courts are unable to measure many important economic factors and virtually all noneconomic ones. Although economic analysis can suggest some interesting lines of inquiry, it could not possibly dictate how courts should balance all relevant considerations. Thus, I agree with Judge Breyer's emphasis on the limitations of economic analysis despite my disagreement with his treatment of spill-related economic damages in Barber Lines. 


\section{Conclusion}

The taxonomy in this paper identified six clusters of decisional criteria that are commonly instrumental in the resolution of legal disputes. ${ }^{151}$ Judicial reliance on economic analysis of microefficiency effects would be appropriate only when courts conclude that this type of consideration should take precedence over all other clusters of potentially relevant decisional criteria. In cases that present important issues pertaining to the allocation of institutional responsibilities, justiciability concerns, or evenhanded justice, those factors are usually outcome-determinative irrespective of any conclusions suggested by economic criteria. In many other cases, considerations of fairness, noneconomic interests, administrability problems, and judicial intuitions about global efficiency effects are more influential than insights derived through attempts at economic analysis.

The discussions of Lee and Barber Lines demonstrate that judicial determination of which weights should be assigned to competing decisional criteria from different clusters requires a legal rather than economic judgment. Microefficiency effects may be worthy of judicial contemplation and may occasionally prove decisive in cases where important variables can be quantified, but systematic economic analysis can seldom provide the ultimate basis for judgments by appellate courts.

151. A possible seventh category could be added that would reflect legal concern with redistributive effects, but none of Judge Breyer's decisions appeared to be significantly influenced by this type of consideration. In Kartell v. Blue Shield of Mass., Inc., 749 F.2d 922, 928 (1st Cir. 1984), cert. denied, 471 U.S. 1029 (1985), he did observe that controlling the "rising costs of medical care" would be desirable, but that is not necessarily a redistributive argument. He also noted that the Sherman Act was intended to protect consumers against unnecessarily high prices, but any redistributive concern there is derived from Congress, not judicial policies. Id. at 931 . 